\title{
VARIATION OF THE WATER TABLE AND SALINITY IN ALLUVIAL AQUIFERS OF UNDERGROUND DAMS IN THE SEMI-ARID REGION OF RIO GRANDE DO NORTE, BRAZIL
}

\author{
VARIAÇÃO DO NÍVEL FREÁTICO E DA SALINIDADE DO AQUÍFERO ALUVIAL \\ EM BARRAGENS SUBTERRÂNEAS NO SEMIÁRIDO DO RIO GRANDE DO NORTE
}

\section{Alexandre de Oiveira LIMA ${ }^{1}$; Francisco Pinheiro LIMA-FILHO ${ }^{2}$; Nildo da Silva DIAS ${ }^{3}$; René Chipana-RIVERA ${ }^{4}$; Miguel FERREIRA NETO ${ }^{3}$; Anderson de Medeiros SOUZA ${ }^{5}$; Priscila Regina do Aragão REGO ${ }^{6}$; Cleyton dos Santos FERNANDES ${ }^{7 *}$}

1. Professor, Universidade do Estado do Rio Grande do Norte, Mossoró, RN, Brazil; 2. Professor, Universidade Federal do Rio Grande do Norte, Natal, RN, Brazil; 3. Professor, Universidade Federal Rural do Semi-Árido, Mossoró, RN, Brazil; 4. Professor, Universidad Mayor de San Andrés, La Paz, Bolívia; 5. Professor, Instituto Federal da Paraíba, Picuí, PB, Brazil; 6. Instituto Nacional de Colonização e Reforma Agrária, Natal, RN, Brazil; 7. Doutorando em Fitotecnia, Universidade Federal Rural do Semi-Árido, Mossoró, RN, Brazil, cleyton1959@hotmail.com.

\begin{abstract}
Despite the growing progress in the construction of underground dams, there are few studies to evaluate and monitor these reservoirs after their construction. Thus, a research study was carried out to evaluate the water table level in alluvial aquifers and water salinity in four underground dams selected in the Cobras river basin, Parelhas municipality, Rio Grande do Norte. Water level variation was monitored using the traditional method and the Ground Penetrating Radar with generation of 3D virtual models. Water samples were collected between the months of December 2010 and December 2011 for electrical conductivity analysis. The results indicate that the accumulation of groundwater and salinity (expressed by electrical conductivity) in the reservoirs were affected by the spatial position within the hydrographic basin (limited occurrence of alluvial aquifer recharge area in headwater sectors) and the presence of surface reservoirs (upstream dams), which promote a more continuous recharge, greater renovation, and reduction of the salinity of the waters of the alluvial aquifer downstream.
\end{abstract}

KEYWORDS: Salinity. Desertification. Hydrochemistry.

\section{INTRODUCTION}

The growing demand for water for human supply is making countries maximize the use of their water reserves. In this context, alternatives have been used to increase water availability, mainly for the diffuse rural demand existing in arid and semi-arid zone (LIMA et al., 2013).

In recent years, the number of underground dams built in Brazil has increased, especially due to the increased Federal public financing, which has prioritized this technology to meet the water needs of rural populations.

In spite of the quantitative advances, there is little research on the environmental impacts of this technology after their construction, involving aspects such as temporal variation and evolution of salinity, and variation of the water level in artificial underground deposits. These parameters are important to guarantee the sustainable use of water by the communities and families that benefit from this rainwater collection and storage technology (SHADEED; LANGE, 2010). Therefore, greater attention must be paid to the management and monitoring of groundwater in a sustainable manner, that is, without causing environmental, economic or social consequences (RAJU et al., 2006; ERTSEN; HUT, 2008; EL-HAMES, 2011; SANTOS et al., 2016).

A study carried out by Fontes Junior et al. (2012) brings important contributions to understand the water quality dynamics from underground dams. However, these investigations do not include a study integrating geological sciences (in particular hydrogeology), with the spatial position within the hydrographic basin associated with existing surface and underground deposits, and local rainfall.

In this context, the objective of this work was to evaluate water salinity and groundwater level variation in the alluvial aquifer in four underground dams of the micro basin of the Cobras river, $\mathrm{RN}$, in the Brazilian semi-arid zone.

\section{MATERIAL AND METHODS}

\section{Characterization of the study area \\ The studies were carried out in four underground dams of the micro basin of the Cobras}


river, in the semi-arid region of the state of Rio Grande do Norte. An outstanding characteristic of this micro basin is its location within the area considered as one of the most affected by the desertification process, being inserted in the Seridó desertification nucleus (NUDES). The climate of the region is classified as BSw $h$ according to criteria established by Köppen (BRASIL, 2002). Based on information from the meteorological station of the municipality of Parelhas/RN, it was possible to define that the rainy season occurs between January and
May, with an average annual rainfall of $612.4 \mathrm{~mm}$, average annual temperature of $26.1{ }^{\circ} \mathrm{C}$, with a minimum of $21.1^{\circ} \mathrm{C}$ and a maximum of $32.0^{\circ} \mathrm{C}$.

\section{Monitoring of water level}

The investigation was carried out in three underground dams $\left(\mathrm{UD}_{1}, \mathrm{UD}_{2}\right.$ and $\left.\mathrm{UD}_{4}\right)$. These three were chosen because they were built at the same time, year 2010, and because they were located in the upper, middle and lower part of the watercourse of the micro basin (Figure 1).

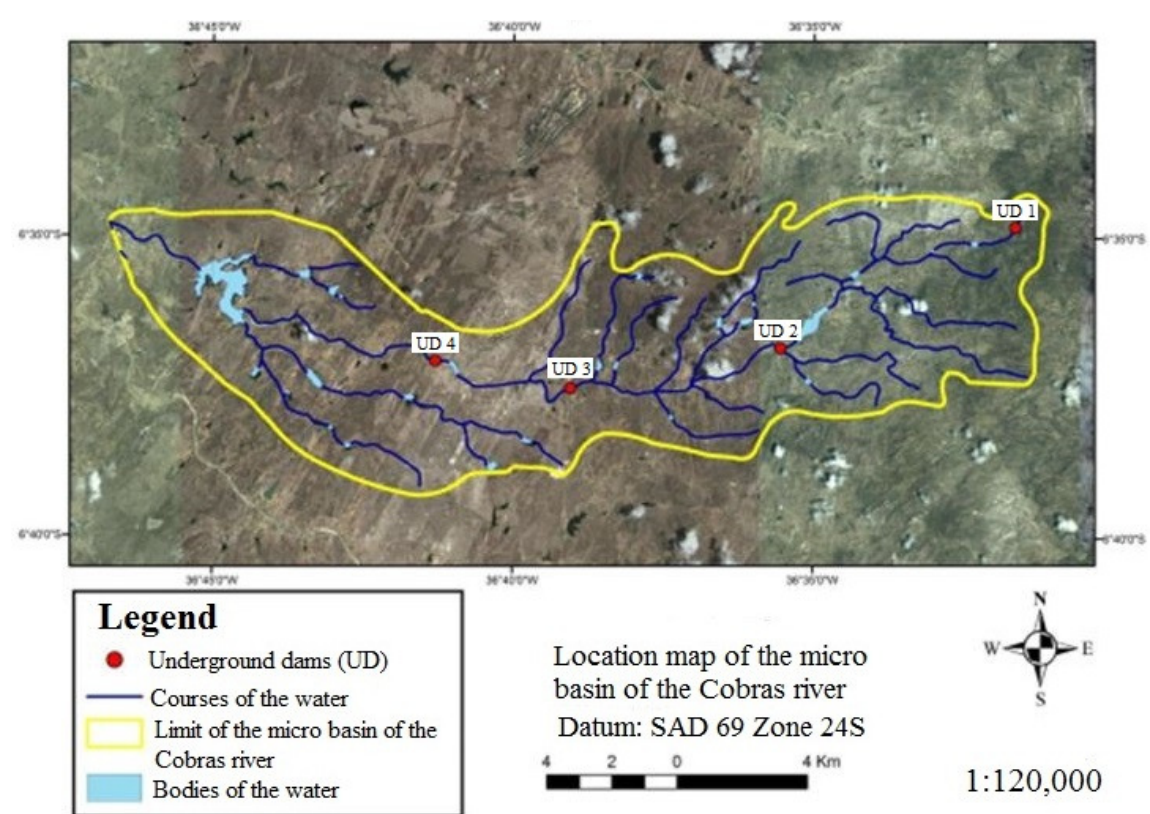

Figure 1. Location of the underground dams (UD) monitored along the micro basin of the Cobras river, RN, 2010.

Measuring water levels of wells in the hydrographic basin was also monitored monthly, using a manual level meter (traditional method). In the case of $\mathrm{UD}_{1}$, the Ground Penetrating Radar method was also used and generated 3D virtual models of the alluvial body, corresponding to the water accumulation area of the underground dam.

\section{Monitoring of groundwater electrical conductivity}

Samples for analysis of the water Electrical Conductivity $\left(\mathrm{EC}_{\mathrm{w}}\right)$ were collected monthly between the months of January and December 2011. The $\mathrm{EC}_{\mathrm{w}}$ was measured and monitored with a portable conductivity meter model Oakton PC 10 series, obtaining the temporal variation of water salinity.

Groundwater electrical conductivity (ECw) was monitored in four underground dams, which are: $\mathrm{UD} 1, \mathrm{UD}_{2}, \mathrm{UD}_{4}$ (dams built in 2010) and $\mathrm{UD}_{3}$ (dam built in 1983) (Figure 1). The first collection of samples was carried out in December 2010, at the end of the dry season of the year, while the second and third collections were made at the end of the rainy and dry season of the year 2011 (June and December months, respectively).

The criteria for the selection of the underground dams were: a) positioning of the underground dam in relation to the areas with springs and to the course of the main river (high, medium and low); b) proximity to surface dams, to evaluate the influence of the integration of surface and groundwater; c) time of construction and operation and d) control in the exploitation of water.

The collected water samples were kept in 500 $\mathrm{mL}$ plastic containers and then taken to the Soil and Water Laboratory of the Agricultural Research Company of Rio Grande do Norte (EMPARN) for $\mathrm{EC}_{\mathrm{w}}$ analysis.

\section{GPR imaging and 3D virtual modeling}

For this procedure, only the underground dam $\mathrm{UD}_{1}$ was selected and the area within the hydrographic basin was imaged to detect basement irregularities, the sedimentary package and the height variation of the groundwater level in the studied 
period. The choice of only one dam was based on an experiment and on the belief that the imaging of one dam represents the others.

The GPR used was the Sir 3000 model of Geological Survey Inc (GSSI) with shielded antennas, resistant connectors, coated and sealed electronic boards, shielding to eliminate interference generated on the ground. After field data acquisition, these were processed in Reflex 5.0 software. In the next step, the radar images were exported and interpreted in the software Opendtect $\mathrm{v}$ 4.4.0, where the 3D model of the alluvial body imaged was created.

\section{Data analysis}

The salinity of the groundwater (expressed by the electrical conductivity) of the micro basin was compared with the rainfall and the variation of the water level monitored during the collection period, and these were plotted using Excel 2010 software.

\section{RESULTS AND DISCUSSION}

\section{Characterization of water salinity in underground dams}

In the collection of samples made at the end of the dry season, in the month of December 2010 (corresponding to the first water collection), the $\mathrm{EC}_{\mathrm{w}}$ increased from upstream to downstream, while in the second collection carried out in June 2011, end of the period in which the dams were at maximum storage capacity and dilution, as well as in the third collection (end of the dry period, December 2011), the increase in water salinity in the downstream direction ceased to exist (Figure 2).

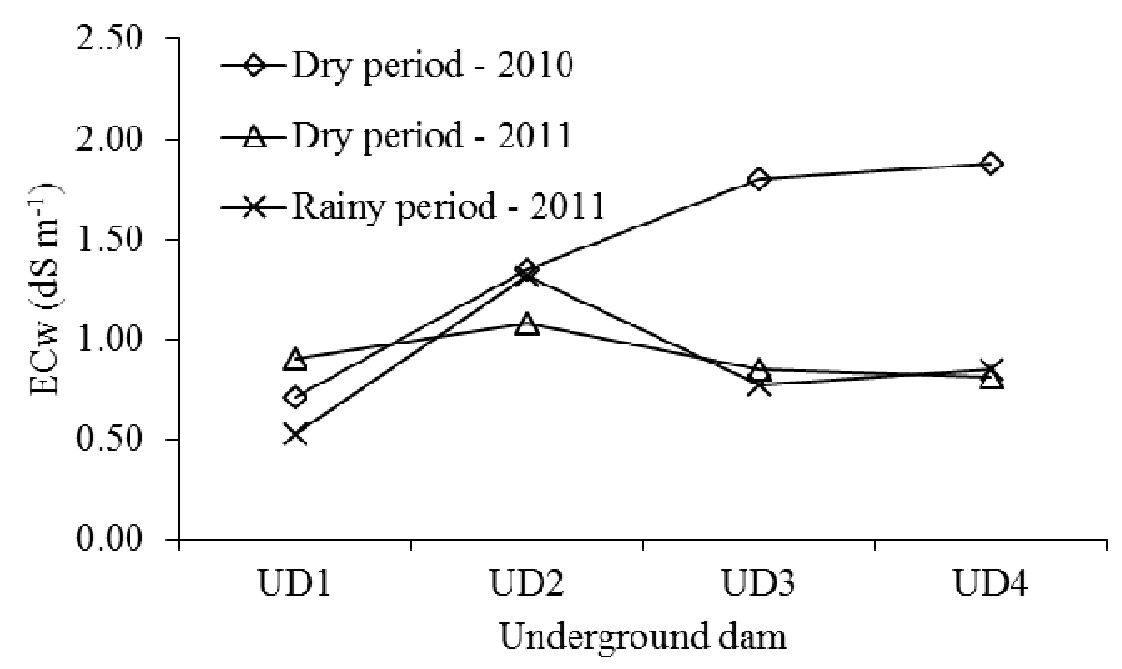

Figure 2. $\mathrm{EC}_{\mathrm{w}}$ of the water in underground dams located along the micro basin of the Cobras river, Parelhas/RN, in the period 2010-2011.

This aspect can be explained by the water accumulation with the functioning of underground dams, which naturally changed the flow dynamics in terms of the presence, accumulation and dilution of the salts. In this condition, salinity is strongly influenced by factors related to the capacity of accumulation and water recharge existing in each underground dam or alluvial aquifer, which in turn reduces ionic concentration (ANDRADE et al., 2010, BAHIA et al., 2011 ; LIMA et al., 2013).

The water samples collected in the months of July and December of 2011 (rainy and dry periods, respectively) in the dams located downstream of the basin $\left(\mathrm{UD}_{3}\right.$ and $\left.\mathrm{UD}_{4}\right)$, due to the large recharge area showed higher effects of ions dilution and the consequent reduction of $\mathrm{EC}_{\mathrm{w}}$ in comparison to samples collected in December 2010 (dry). Another aspect worth mentioning is that, although $\mathrm{UD}_{3}$ has been built twenty-seven years ago and $\mathrm{UD}_{4}$ was only one year old, these dams had very close $\mathrm{EC}_{\mathrm{w}}$ values. One of the possible explanations for the control of salinity in $\mathrm{UD}_{3}$ over the years is the frequency of water use for domestic consumption of five families, about $270 \mathrm{~m}^{3}$ of water per month.

Although studies must continue in other underground dams, these results indicate that if there is consumption there will be renewal of water and salts, therefore the salinization process will not be triggered. Other studies also show that rainfall and the continuous use of water from an underground dam exert a strong influence on salinity levels in dry periods of the year (LOPES, 2013, LIMA et al., 2017). 


\section{Variation of salinity associated with the water level of underground dams}

The water stored in the $\mathrm{UD}_{1}$ had a reduction in the $\mathrm{EC}_{\mathrm{w}}$ between the months of January and March 2011 due to the rainy season in the region
(Figure 3). This reduction in ECw was possibly due to the dilution of the salts present in the deposit by the rainwater. As of the month of April, the gradual increase in $\mathrm{EC}_{\mathrm{w}}$ predominated, reaching $0.85 \mathrm{dS} \mathrm{m}^{-1}$ in December.

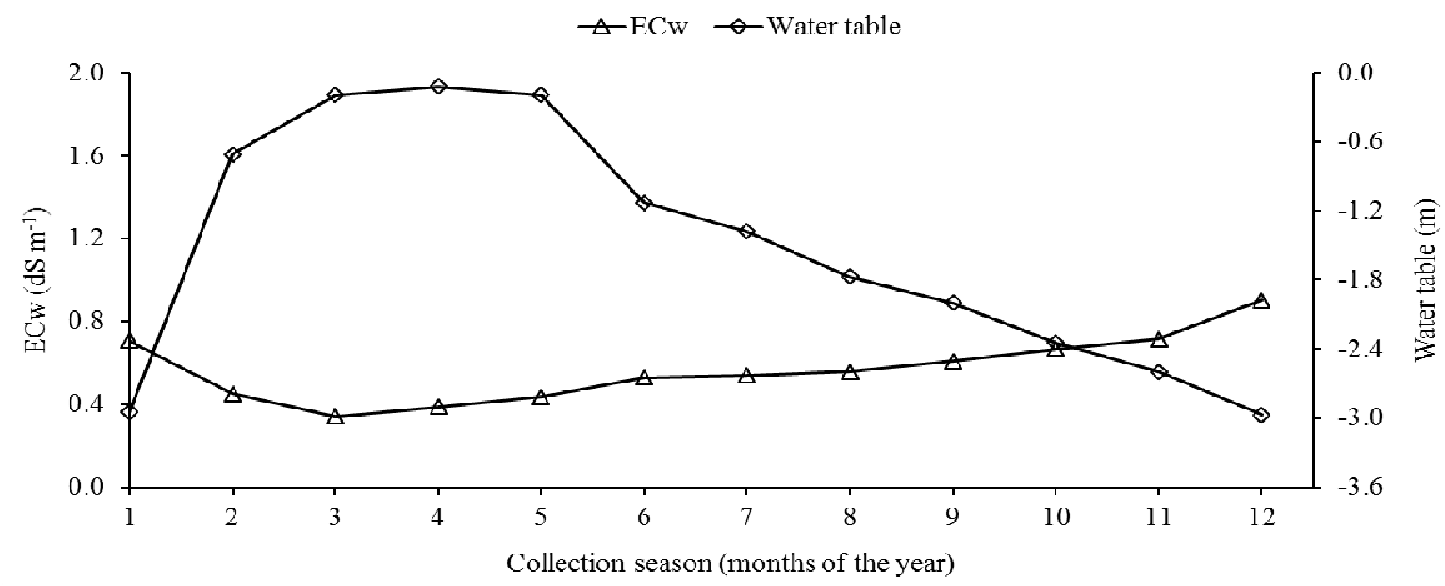

Figure 3. Monthly variations of $\mathrm{EC}_{\mathrm{w}}$ and depths of the water table of $\mathrm{UD}_{1}$, upstream, near the source in the micro basin of the Cobras river, RN, between January and December 2011.

With respect to the variation of the groundwater level of $\mathrm{UD}_{1}$, there is an elevation of the water table (decreasing its depth and tending to be flat) between January and March 2011, as can be seen in Figure 3. This fact is associated with the water supply coming from the recharges by the precipitations that occurred in the period. Between March and May there is a stabilization of this fluctuation, while a gradual decline of the water table begins in May, resulting in an almost total emptying of the underground dam, in the middle of December.

With the descent of the phreatic level, water salinity increased in the alluvial aquifer (Figure 3), establishing a relation between the greater depth of the phreatic level, greater emptying of the reservoir, and greater concentration and/or precipitation of salts, especially salts with lower solubility.

Usually alluvial aquifers, in the areas closest to the springs/headwaters, have limited accumulation/retention potential of the recharge waters, and are easily affected by dry periods or by large exploitations, due to the reduced size of the alluvial sedimentary deposits associated with greater slope and gradient in the headwaters of the river basin, which interfere in the sedimentary dynamics.

In this case, the transport of sediments in the headwaters of rivers exceeds the deposition, and the lower the alluvial sediment deposition, the lower the capacity of the alluvial aquifer reservoir to be formed upstream of the underground dams, limiting the formation of saturated thicknesses and underground reserves.

Lima et al. (2013) show the importance of not constructing underground dams near the springs due to the limited accumulation / retention capacity of the recharge waters. Cirilo et al. (2003), when evaluating underground dams constructed in the state of Pernambuco, also pointed to this limited recharge area as one of the main causes of the failure of some underground dams in that state.

In relation to $\mathrm{UD}_{2}$ (Figure 4), the variations of $\mathrm{EC}_{\mathrm{w}}$ and water table level were very different from those observed in $\mathrm{UD}_{1}$, that is, there is no clear relation between $\mathrm{EC}_{\mathrm{w}}$ increase with groundwater retraction (increase in depth). The variation of the water table in $\mathrm{UD}_{2}$ was approximately $0.57 \mathrm{~m}$, value much lower than the $2.85 \mathrm{~m}$ found in $\mathrm{UD}_{1}$ (Figure 3 ) and the $3.08 \mathrm{~m}$ observed in $\mathrm{UD}_{4}$ (Figure 5). As of July, there is a gradual decrease of both monitored parameters until the month of October, during which time the water table continues to fall and the salinity starts to have a slight tendency to increase.

It was also verified, as already observed for the water table, a low amplitude of variation of $\mathrm{EC}_{\mathrm{w}}$ in $\mathrm{UD}_{2}$. This specific characteristic can be explained by the presence of a dam upstream of this underground dam. This water body maintains a continuous recharge of the alluvial aquifer in the downstream section over time, a fact that can lead to less abrupt changes in salinity at the moment of rainfall, as occurred in $\mathrm{UD}_{1}$. 


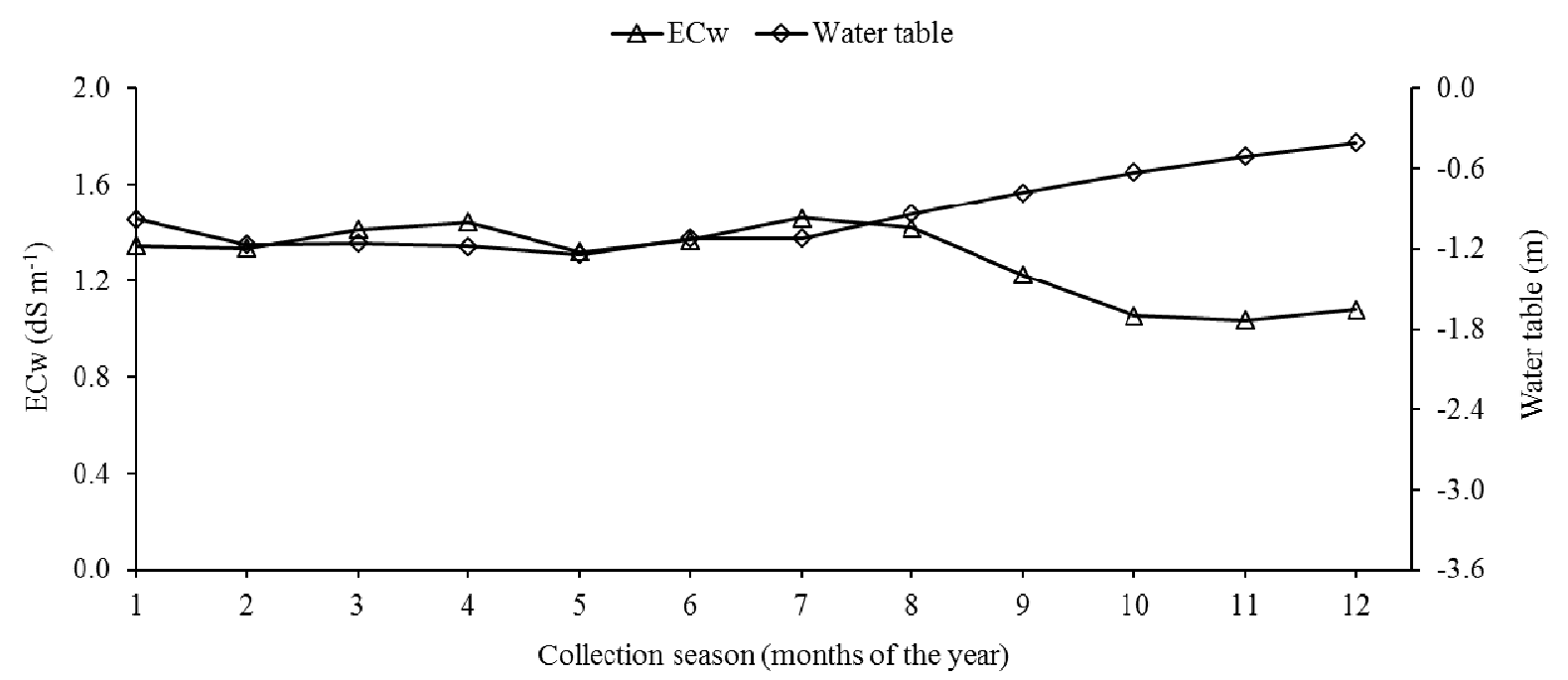

Figure 4. Monthly variations of $\mathrm{EC}_{\mathrm{w}}$ and depths of the water table of $\mathrm{UD}_{2}$, in the micro basin of the Cobras river, RN, between January and December 2011.

Thus, the influence of surface works, such as the dams built along the semi-arid basins, which influence the frequency of recharge, renewal and reduction of the salinity of the alluvial aquifers of the underground dams, suggesting the need for integrated management of surface and groundwater.

Regarding $\mathrm{UD}_{4}$, it was observed that the rains tend to occur between January and April, reducing from May to December. The beginning of the occurrence of the rains also marks the period of recovery/rise of the water table (becoming flatter), in general between January and April, remaining at a constant level until the beginning of June, and then progressively decreasing to a critical level in the month of December, when the saturated thickness of the aquifer is very small or zero.

In relation to the electrical conductivity of water in $\mathrm{UD}_{4}$ (Figure 5), with the increase of rainfall between January and April, there is a tendency of $\mathrm{EC}_{\mathrm{w}}$ reduction, which shows an abrupt fall between January and February (probably due to the dilution of salts with recharge of the aquifer), and a continuous and progressive trend of reduction from February to December.

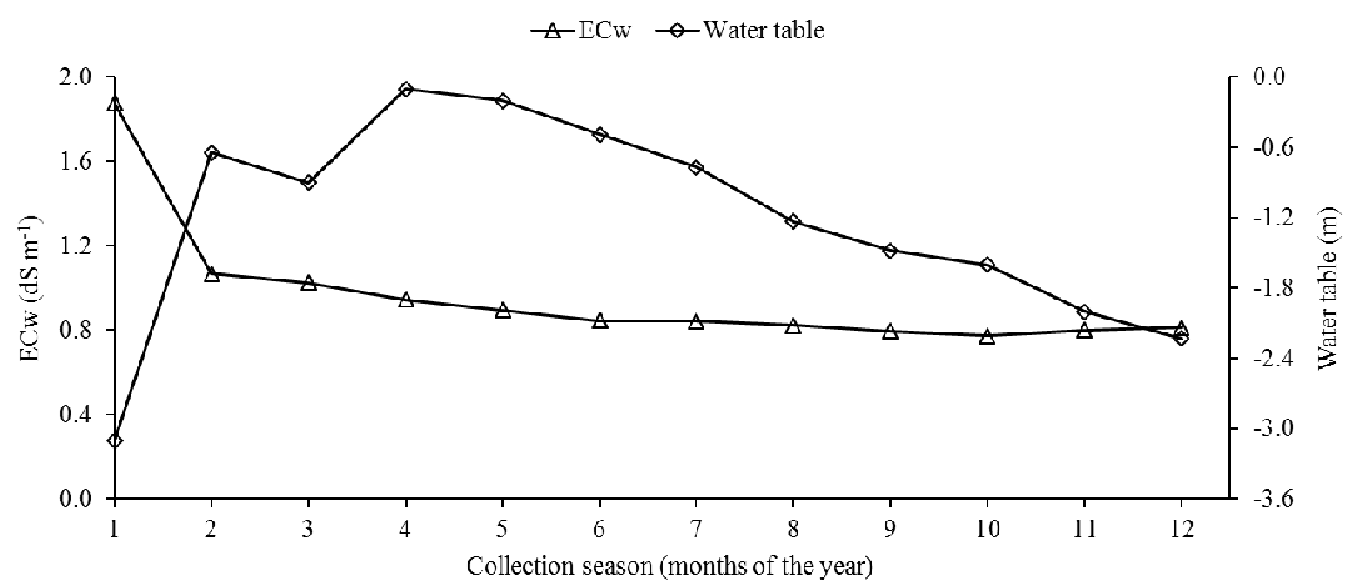

Figure 5. Monthly variations of $\mathrm{EC}_{\mathrm{w}}$ and depths of the water table of $\mathrm{UD}_{4}$, in the micro basin of the Cobras river, RN, between January and December 2011.

Two aspects deserve to be highlighted in $\mathrm{UD}_{4}$; the first was the high $\mathrm{EC}_{\mathrm{w}}$ reduction, reaching December with the lowest water salinity $(0.813 \mathrm{dS}$ $\mathrm{m}^{-1}$ ) among the three dams monitored. The second was that between the beginning and the end of the monitoring (January and December 2011) the water table level increased by $0.87 \mathrm{~m}$ (Figure 5). It should 
be noted that at the beginning of monitoring this underground dam had the highest salinity.

A common feature in the three monitored dams was that since June there was a gradual reduction in the water table, although with different intensities, mainly in $\mathrm{UD}_{2}$, since the deposits did not remain static.

Three factors may explain this phenomenon: the first refers to the decrease of rainfall as shown in Figures 3, 4 and 5; the second, and most probable, results from the existence of fractures, very common in the crystalline basement of the region in which the micro basin is inserted, located under the influence of metamorphic mica schists of the Seridó Formation. This type of rock has generally vertical foliations which would facilitate the losses in the reservoirs, making it possible for the water accumulated in the underground dams to feed the fissure aquifer and maintain the waters of this reservoir with salinity levels lower than those in other regions of the Rio Grande do Norte state. Thus, when planning the underground dams, this fracturing condition of the crystalline basement that

A.

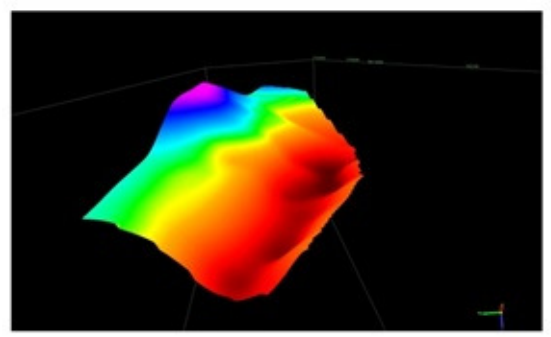

C.

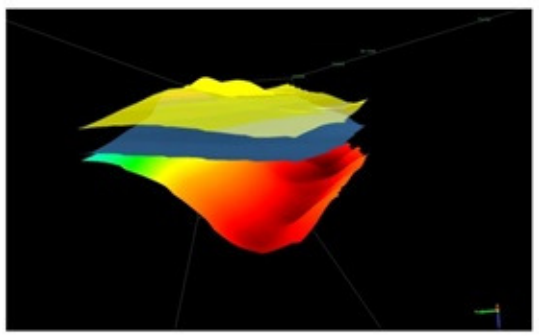

serves as the basis for the reservoir needs to be observed with greater attention. For Cirilo et al. (2003), in a study of underground dams monitoring, stated that problems related to the placement of the impermeable septum (200-micron-thick plastic tarpaulin) are one of the main factors of failure of underground dams. The third factor is related to losses by the impermeable septum used to block the passage of water.

\section{Water level imaging in $\mathrm{UD}_{1}$}

The literature on water level imaging in underground dams in the northeastern semi-arid region is very scarce, making it difficult to discuss the results obtained in this study.

The water table in the entire catchment area of the underground dam $\mathrm{UD}_{1}$ was identified in the 3D GPR profile (Figure 6). Lahouar and Al-Qadi et al. (2014) reported good sensitivity of the GPR to map the water level and its temporal variation, since they were able to detect the presence of the water table within multiple and ambiguous reflectors to a depth of approximately $8 \mathrm{~m}$.

\section{B.}

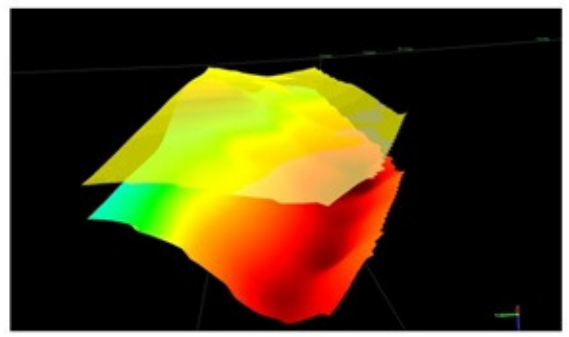

D.

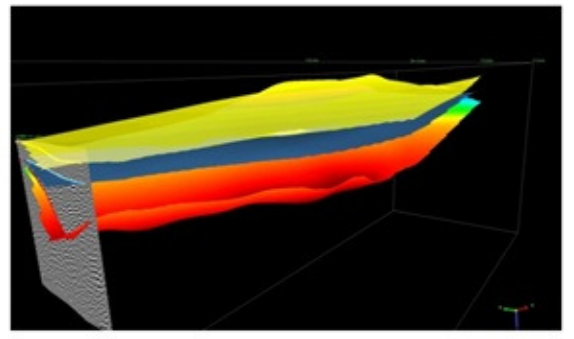

Figure 6. Imaging of the crystalline basement of the hydrographic basin area (A), topographic surface and crystalline basement (B), view of the reservoir, highlighting the water level in the imaging (C) and lateral view of the basin of the monitored underground dam (D).

The water level generates a reflection with higher energy due to the decreasing velocity at the water level, as well as the difference in the dielectric properties of the fluid in comparison to the other materials in the place (CASSIDY, 2007).

In the case of the use of GPR for the leasing process in an area where there is a high water table, depending on recharge process in that location, it will be possible to determine its position, and with that, to anticipate additional costs arising from the need for lowering the water level. In addition to this factor, additional care with the people involved with the construction process may have an impact on the financial costs of the work. In this way, the information generated with the previous imaging 
will be of fundamental importance for the planning of the process of construction of underground dams.

Therefore, it will be possible to propose a model of sustainable management of aquifers, allowing a planning that takes into account local water availability with the needs of rural communities, in order to ensure access to water during the most critical period of the year.

\section{CONCLUSIONS}

The accumulation of water and the salinity of the groundwater of the alluvial aquifer in the underground dams are strongly influenced by the spatial position within the hydrographic basin (limited occurrence of recharge area due to lower deposition rate and accumulation of alluvial sediments in headwater sectors of the river), presence of surface reservoirs (upstream dams), which promote a more continuous recharge, greater renovation, and reduction of the salinity of the waters of the alluvial aquifer downstream.
The open fracture planes of the fractured crystalline aquifer rocks may favor a greater transfer of water from the overlying alluvial aquifer by descending vertical drainage to the underlying crystalline aquifer, which could promote the renewal of alluvial aquifer reserves and reduce the salinity of the groundwater.

However, this structural conditioning and hydraulic interconnection between the alluvial aquifers and the underlying "fractured" aquifer need to be studied, confirmed and quantified in greater detail in the light of temporal and spatial monitoring data in the area, with no elements still to affirm that these factors act decisively to diminish the salinity of the waters of the alluvial aquifer implanted in the underground dams in the studied domain.

The 3D GPR profile method of the alluvial body, corresponding to the $\mathrm{UD}_{1}$ hydrographic basin, identified the irregularities of the basement, the space occupied by the sedimentary package and the water table of the reservoir, and could be used later to monitor the water level fluctuation in these reservoirs.

RESUMO: Apesar do crescente avanço na construção de barragens subterrâneas, há poucos estudos de avaliação e monitoramento das barragens subterrâneas após a sua construção. Assim, foi realizada uma pesquisa com o objetivo de avaliar a salinidade da água e a variação do nível freático em aquífero aluvial em quatro barragens subterrâneas selecionadas na microbacia do rio das Cobras, município de Parelhas, Rio Grande do Norte. As amostras de água foram coletadas entre os meses de dezembro de 2010 a dezembro de 2011 para análise da condutividade elétrica. A variação do nível da água foi monitorada utilizando método tradicional e o Ground Penetrating Radar com geração de modelos virtuais 3D. Os resultados indicam que a acumulação da água subterrânea e a sua salinidade (expressa pela condutividade elétrica) nos reservatórios foram afetadas pela posição espacial dentro da bacia hidrográfica (ocorrência limitada de área de recarga do aquífero aluvial em setores de cabeceiras do rio) e pela presença de reservatórios superficiais (açudes à montante), os quais promovem uma recarga mais contínua, maior renovação, e redução da salinidade das águas do aquífero aluvial à jusante.

PALAVRAS-CHAVE: Salinidade. Desertificação. Hidroquímica.

\section{REFERENCES}

ANDRADE, E. M.; LOPES, F. B.; PALÁCIO, H. A. Q.; AQUINO, D. N.; ALEXANDRE, D. M. B. Land use and groundwater quality: The case of Baixo Acaraú Irrigated Perimeter, Brazil. Revista Ciência Agronômica, Fortaleza, v. 41, n. 2, p. 208-215, 2010. http://www.ccarevista.ufc.br/seer/index.php/ccarevista/article/view/635

BAHIA, V. E.; FENZL, N.; LEAL, L. R. B.; MORA-LES, G. P.; LUÍZ, J. G. Caracterização hidrogeoquímica das águas subterrâneas na área de abrangência do reservatório de abastecimento público do Utinga - Belém (PA). Revista Águas Subterrâneas, Cotia, v. 25, n. 1, p. 1-14, 2011.

http://dx.doi.org/10.14295/ras.v25i1.19499

BRASIL. Caracterização dos recursos naturais de uma área piloto do núcleo de desertificação do Seridó, Estados do Rio Grande do Norte e da Paraíba. Rio de Janeiro: Embrapa Solos, 2002. 53 p. 
CASSIDY, N. J. A review of practical numerical modelling methods for the advanced interpretation of groundpenetrating radar in nearsurface environments. Near Surface Geophysics, Houten, v. 5, n. 1, p. 5-21, 2007. http://dx.doi.org/10.3997/1873-0604.2006014

CIRILO, J. A.; COSTA, W. D.; GOLDEMBERG, D.; ABREU, G. H. F.; AZEVEDO, L. G. T.; BALTAR, A. M. Soluções para o suprimento de água de comunidades rurais difusas no semi-árido brasileiro: Avaliação de barragens subterrâneas. Revista Brasileira de Recursos Hídricos, Porto Alegre, v. 8, n. 4, p. 5-24, 2003. https://www.abrh.org.br/SGCv3/index.php?PUB=1\&ID=34\&SUMARIO=1533

EL-HAMES, A. S. Determination of the transient water table rise behind constructed underground dam. Arabian Journal of Geoscince, Riade, v. 5, n. 6, p. 1359-1366, 2011. https://doi.org/10.1007/s12517-0110299-2

ERTSEN, M.; HUT, R. Two waterfalls do not hear each other. Sand-storage dams, science and sustainable development in Kenya. Physics and Chemistry of the earthe, Amsterdã, v. 34, n. 1-2, p. 14-22, 2008. https://doi.org/10.1016/j.pce.2008.03.009

FONTES JUNIOR, R. V. P.; MONTENEGRO, A. A. A.; MONTENEGRO, S. M. G. L.; SANTOS, T. E. M. Estabilidade temporal da potenciometria e da salinidade em vale aluvial no semiárido de Pernambuco. Revista Brasileira de Engenharia Agrícola e Ambiental, Campina Grande, v. 16, n. 11, p. 1188-1197, 2012. http://dx.doi.org/10.1590/S1415-43662012001100007

LAHOUAR, S.; AL-QADI, I. L. Automatic detection of multiple pavement layers from GPR data. NDT \& E International, Amsterdã, v. 41, n. 1-2, p. 69-81, 2008. https://doi.org/10.1016/j.ndteint.2007.09.001

LIMA, A. O.; DIAS, N. S.; FERREIRA NETO, M.; SANTOS, E. J.; REGO, P. R. A.; LIMA-FILHO, F. P. Barragens subterrâneas no semiárido Brasileiro: Análise histórica e metodologia de construção. Irriga, Botucatu, v. 18, n. 2, p. 200-211, 2013. http://dx.doi.org/10.15809/irriga.2013v18n2p200

LIMA, A. O.; LIMA-FILHO, F. P.; DIAS, N. S.; REGO, P. R. A.; FERREIRA NETO, M. Mechanisms controlling surface water quality in the Cobras river sub-basin, northeastern Brazil. Revista Caatinga, Mossoró, v. 30, n. 1, p. 181-189, 2017. http://dx.doi.org/10.1590/1983-21252017v30n120rc

LOPES, H. L.; CABRAL, J. J. S. P.; ARAÚJO FILHO, J. C.; MONTENEGRO, S. M. G. L. Mapeamento de áreas aluvionares no semiárido brasileiro por meio de dados colaterais e imagens orbitais. Revista Brasileira de Engenharia Agrícola e Ambiental, Campina Grande, v. 17, n. 7, p. 763-769, 2013.

http://dx.doi.org/10.1590/S1415-43662013000700011

RAJU, N. J.; REDDY, T. V. K.; MUNIRATHNAM, P. Subsurface dam to harvesting rainwater. A case study of the Swarnmukhi river basin, Souther India. Hydrogeology Journal, Menlo Park, v. 14, n. 4, p. 526-531, 2006. https://doi.org/10.1007/s10040-005-0438-5

SANTOS, S. M; PAIVA, A. L. R; SILVA, V. F. Qualidade da Água em Barragens Subterrãneas no semiárido. Revista Brasileira de Agricultura Irrigada, Fortaleza, v. 10, n. 3, p. 651-662, 2016. https://doi.org/10.7127/RBAI.V10N300394

SHADEED, S.; LANGE, J. Rainwater harvesting to alleviate water scarcity in dry conditions: A case study in Faria Catchment, Palestine. Water Science and Engineering, Amsterdã, v. 3, n. 2, p. 32-143, 2010. https://doi.org/10.3882/j.issn.1674-2370.2010.02.002 